ARTICLE

\title{
A first assessment of atresia in the Chilean jack mackerel Trachurus murphyi (Teleostei, Carangidae) from the South-eastern Pacific Ocean
}

\author{
Primera evaluación de la Atresia en el jurel Trachurus murphyi (Teleostei, Carangidae) \\ en el Pacífico sureste
}

\begin{abstract}
Paola González-Kother ${ }^{\circledast 1,2^{*}}$, M. Teresa González ${ }^{3}$ and Marcelo E. Oliva ${ }^{\circledR 3,4}$
${ }^{1}$ Programa de Doctorado en Ciencias Aplicadas mención Sistemas Marinos Costeros, Universidad de Antofagasta, P.O. Box 170, Antofagasta, Chile

${ }^{2}$ Facultad de Ciencias, Universidad Católica de la Santísima Concepción, Alonso de Ribera 2850, P.O. Box 297, Concepción, Chile ${ }^{3}$ Instituto de Ciencias Naturales "Alexander von Humboldt", Facultad de Ciencias del Mar y Recursos Biológicos, Universidad de Antofagasta, P. O. Box 170, Antofagasta, Chile

${ }^{4}$ Instituto Milenio de Oceanografía, Universidad de Concepción, P.O. Box 160-C, Concepción, Chile

*Corresponding author: pgonzalez@ucsc.cl

Resumen.- El jurel, Trachurus murphyi sustenta una importante pesquería en el Pacífico sureste la que ha declinado considerablemente en el tiempo. T. murphyi tiene un desarrollo ovárico asincrónico con desoves oceánicos (septiembre a enero). A pesar de la importancia económica de este recurso, se desconocen aspectos críticos de su biología, como las características y la dinámica de la atresia, que pueden afectar el rendimiento reproductivo. Hembras de T. murphyi capturadas en distintas estaciones de desove fueron analizadas para describir los patrones de prevalencia e intensidad de atresia. Se realizaron modelos lineales generales (GLM) usando prevalencia e intensidad de atresia como variables de respuesta e índice gonadosomático, factor de condición, temperatura de la superficie del mar, folículos postovulatorios y mes/año como variables predictoras. La fecundidad parcial y la fecundidad relativa se compararon entre hembras con atresia, hembras con folículos postovulatorios y hembras no atrésicas. Las etapas de atresia identificadas fueron alfa, beta y gamma. El GLM mostró que las variaciones en la prevalencia e intensidad de la atresia fueron explicadas por todas las variables, excepto el factor de condición para la prevalencia y el índice gonadosomático para la intensidad de atresia. De acuerdo con estos resultados, la dinámica de alfa y beta atresia pueden considerarse un potencial proxy para cualquier interrupción de la temporada de desove. La fecundidad parcial y la fecundidad relativa fueron más bajas en comparación con otros Trachurus spp. En esta especie, se hace una primera evaluación que compara la fecundidad entre hembras con y sin atresia.
\end{abstract}

Palabras clave: Atresia, factor de condición, fecundidad, estación de desove, Trachurus

\begin{abstract}
The Chilean jack mackerel Trachurus murphyi support an important fishery in the South-eastern Pacific Ocean and has declined considerably over time. T. murphyi have asynchronous ovarian development with an oceanic spawning (September to January). Despite the economic importance of this resource critical issue such as characteristics and dynamics of atresia, which affect the reproductive output, are unknown. Females of $T$. murphyi caught in different spawning seasons were analysed to describe patterns of prevalence and intensity of atresia. General linear models (GLM) were performed by using prevalence and intensity atresia as response variables and gonadosomatic index, condition factor, sea surface temperature, postovulatory follicles and month/year as explanatory variables. The batch fecundity and relative fecundity were compared between females showing atresia, postovulatory follicles and non-atretic females. The stages of atresia identified were alpha, beta and gamma. The GLM showed that variations in the prevalence and intensity of atresia were explained for all variables, except condition factor for prevalence, and gonadosomatic index for intensity of atresia. According to our results, the dynamic of alpha and beta atresia could be considered a potential proxy for any disruption of spawning season. The batch fecundity and relative fecundity were lowest compared with other Trachurus spp. This is the first assessment comparing fecundity between atretic and not atretic females for this species.
\end{abstract}

Key words: Atresia, condition factor, fecundity, spawning season, Trachurus

\section{INTRODUCTION}

In the South-eastern Pacific Ocean (SEP), industrial fisheries for the highly migratory Chilean jack mackerel Trachurus murphyi Nichols, 1920. The main fishery includes the coast off Peru and Chile, extending from the central coast of Chile to the South-west Pacific Ocean, reaching the coast around New Zealand and Tasmania has been described (Serra 1991, Cárdenas et al. 2009, Vásquez et al. 2013). The peak in the catch was achieved in the 1990s, (ca., 4,600,000 tons) after which the catch for all fleets steadily decreased and for 2019 the South Pacific Regional Fisheries Management Organisation recommended a limit of capture of 591,000 tons (SUBPESCA 2018). The main reason explaining this situation was the strong fishing mortality and potentially unfavourable environmental conditions (Dragon et al. 2018). 
In the SEP, Chilean jack mackerel conform a single large population (Poulin et al. 2004, Cárdenas et al. 2009) that can be found in three different habitats (Arcos et al. 2001) according to its life history: a) nursery ground area, b) coastal feeding area and c) a large, main oceanic spawning area off central Chile (Bertrand et al. 2004, Cubillos et al. 2008, Vásquez et al. 2013). Interestingly, otolith chemistry indicates that all adult Chilean jack mackerel come from the same oceanic spawning area (Ashford et al. 2011). Recently, Parada et al. (2017) indicated the presence of a potential new spawning and nursery ground area associated with the seamount region in the Challenger break and the East Pacific ridge $\left(32^{\circ} \mathrm{S}-39^{\circ} \mathrm{S}\right.$ and $\left.105^{\circ}-126^{\circ} \mathrm{W}\right)$.

Chilean jack mackerel can spawn throughout their whole distribution (Taylor 2002, Gerlotto et al. 2012), and the time extension of the spawning period varied between area and years (Perea et al. 2013). For the main oceanic spawning area from central coast of Chile $\left(32^{\circ} \mathrm{S}-38^{\circ} \mathrm{S}, 80^{\circ} \mathrm{W}-92^{\circ} \mathrm{W}\right)$ the spawning period extends from September to January when mature fish begin the annual migration from the feeding area to the oceanic spawning area; that extends more than 1,800 km off the coast (Cubillos et al. 2008, Leal et al. 2013).

Like other Trachurus species, T. murphyi present asynchronous ovarian development (Leal et al. 2013). George (1995) suggests an indeterminate fecundity for $T$. murphyi based in the frequency of oocytes size distribution, length of the spawning season as well presence of atresia. A generalized prevalence of atresia and resorption of mature oocytes at the end of the spawning season has been described for fishes with indeterminate fecundity (West 1990). Accordingly, fecundity estimates should be made using the most advances development oocytes (hydrated oocytes) instead the vitellogenic oocytes (Saborido-Rey \& Kjesbu 2005). For T. murphyi, is not easy to find females harbouring hydrated oocytes during the spawning season (George 1995, Leal et al. 2013), consequently vitellogenic oocytes could be counted, and in this case, atresia must be quantified (Saborido-Rey \& Kjesbu 2005). Atresia is a normal process of oocyte renewal (Kurita et al. 2003, Lowerre-Barbieri et al. 2011), which increases at the cessation of spawning when all remaining vitellogenic oocytes are resorbed (Saborido-Rey \& Kjesbu 2005).

In mature females, atresia can occur at any time during the reproductive cycle. Sometime, females delay its reproduction, inclusive for one year, increasing the prevalence and intensity of atretic oocytes. In highly migratory species, such as T. murphyi, it is expected that during the spawning period, some females will have atretic oocytes due to potential energy loss during annual migration. As atresia can have strong consequences in recruitment, the knowledge of the spatio-temporal dynamics of this process is important to assign the status of female in the spawning stock during spawning season. Atresia can have direct effect on the number of eggs that females can produce. Like other reproductive traits, atresia depends on the female's physiological conditions (e.g., age, length, condition) and environmental factors (e.g., temperature). Therefore, the main objectives were (1) to describe the phases of atresia in T. murphyi caught during the post-migration spawning period in order to evaluate the spawning history, (2) to determine the prevalence and intensity of atresia in different spawning periods and its relation with physiological conditions and environmental factors and (3) to determine the impact of atresia in the fecundity.

\section{MAterials AND METHODS}

\section{ETHICAL STATEMENT}

Ethical approval was not required for this study, due all specimens were collected as part of research cruises that are performed for the evaluation of spawning biomass (DEPM) in the Chilean jack mackerel, Trachurus murphyi from oceanic spawning area off central Chile (Table 1). Fish arrived dead at fishing port. No samples were collected by the authors; permission was granted to use biological database and gonads of all fish.

Table 1. Cruises performed for the evaluation of spawning biomass (DEPM) in the Chilean jack mackerel, Trachurus murphyi from oceanic spawning area off central Chile between 2004 and 2014 / Cruceros realizados para evaluar biomasa desovante (MPDH) en el jurel, Trachurus murphyi desde el área de desove en Chile central entre el 2004 y 2014

\begin{tabular}{|c|c|c|c|c|c|c|}
\hline & \multicolumn{6}{|c|}{ Cruise } \\
\hline & 2004 & 2005 & 2006 & $2012-2013$ & 2013 & 2014 \\
\hline $\mathrm{S}$ & $\mathrm{S} 1$ & $\mathrm{~S} 2$ & S3 & S4 & S5 & S6 \\
\hline Months by $\mathrm{S}$ & Nov & Nov & Nov & Dec/Jan & Dec & Nov/Dec \\
\hline \multirow[t]{2}{*}{ Lat $\left({ }^{\circ} \mathrm{S}\right)$} & $32^{\circ} 20^{\prime}-38^{\circ} 00^{\prime}$ & $34^{\circ} 20^{\prime}-38^{\circ} 40^{\prime}$ & $33^{\circ} 14^{\prime}-38^{\circ} 50^{\prime}$ & $32^{\circ} 12^{\prime}-36^{\circ} 30^{\prime}$ & $29^{\circ} 53^{\prime}-35^{\circ} 40^{\prime}$ & $32^{\circ} 33^{\prime}-36^{\circ} 30^{\prime}$ \\
\hline & & & & $34^{\circ} 57^{\prime}-35^{\circ} 18^{\prime}$ & & $32^{\circ} 41^{\prime}-38^{\circ} 00^{\prime}$ \\
\hline \multirow[t]{2}{*}{ Long $\left({ }^{\circ} \mathrm{W}\right)$} & $75^{\circ} 41^{\prime}-91^{\circ} 51^{\prime}$ & $76^{\circ} 50^{\prime}-87^{\circ} 54^{\prime}$ & $71^{\circ} 01^{\prime}-91^{\circ} 46^{\prime}$ & $71^{\circ} 59^{\prime}-88^{\circ} 40$ & $71^{\circ} 50^{\prime}-76^{\circ} 50^{\prime}$ & $74^{\circ} 25^{\prime}-85^{\circ} 48^{\prime}$ \\
\hline & & & & $73^{\circ} 47^{\prime}-74^{\circ} 08^{\prime}$ & & $72^{\circ} 12^{\prime}-86^{\circ} 57^{\prime}$ \\
\hline $\operatorname{SST}\left({ }^{\circ} \mathrm{C}\right)$ & $15.0-19.0$ & $14.5-17.5$ & $13-17$ & $15-17 / 13-13.5$ & $13-14.4$ & $15.5-16.4 / 13.9-15.1$ \\
\hline $\mathrm{FL}(\mathrm{cm})$ & $32(23-58)$ & $32(25-49)$ & $36(27-55)$ & $34(23-48) / 30(25-36)$ & $36(27-64)$ & $37(29-47) / 37(24-49)$ \\
\hline $\mathrm{BW}(\mathrm{g})$ & $115-1850$ & $200-1110$ & $240-1800$ & $165-1270 / 180-525$ & $250-3090$ & $330-1200 / 125-1300$ \\
\hline $\mathrm{n}$ & 988 & 596 & 727 & $287 / 139$ & 431 & $162 / 320$ \\
\hline
\end{tabular}

$\mathrm{S}=$ spawning season, $\mathrm{Lat}=$ latitude, Long= longitude, $\mathrm{SST}=$ sea surface temperature, $\mathrm{FL}=$ fork length, $\mathrm{BW}=\mathrm{body}$ weight, $\mathrm{n}=$ number of females 


\section{SAMPLE COLLECTION}

Mature females $(n=3,650)$ were sampled along the spawning area off central Chile $\left(30^{\circ}-39^{\circ} \mathrm{S} ; 71^{\circ}-88^{\circ} \mathrm{W}\right)$, according to the methodology described by Sepúlveda et al. (2009). Briefly, for each successful trawl a set of females were selected at random. Females caught were longer than $23 \mathrm{~cm}$ fork length. Fork length (FL, cm) and body weight $(\mathrm{BW}, \mathrm{g})$ were measured and gonad tissue samples were collected on board. Besides, sea surface temperature (SST) was recorded at each trawl.

Gonads were processed for histology using standard protocols. The ovaries were fixed in $10 \%$ neutral buffered formaldehyde at board of fishing vessels. In the laboratory a cross-section of tissue was sampled from the middle parts of the ovary. Each sample was embedded in paraffin, sectioned transversely with a thickness of $5 \mu \mathrm{m}$ and stained with haematoxylin and eosin $(\mathrm{H}+\mathrm{E})$. The histological methodology was followed Brown-Peterson et al. (2011) and applied for Leal et al. (2013) to describe and characterize the reproductive maturity phases for this species.

The significance of potential differences in FL and BW between spawning periods was analysed using KruskalWallis test. Differences between immature and mature females for FL and BW were analysed using Mann-Whitney test. Gonadosomatic index (GSI) that indicate the tendency of the degree of gonadic maturity in its reproductive cycle, were recorder for each specimen. GSI was calculated as $\mathrm{GSI}=(\mathrm{GW} / \mathrm{BW}) \times 100($ Zimmermann 1997); where GW is gonad weight $(\mathrm{g})$. Condition factor $(K)$ was calculated as an overall measure of robustness of the fish in relation to reproductive maturity phases. $K$ was estimated as $K=(\mathrm{BW} /$ $\left.\mathrm{FL}^{3}\right)$ x 100 (Zimmermann 1997). The mean values of GSI and $K$, obtained for the different maturity stages during each sampled period, were compared using the Kruskal-Wallis tests. Potential relationships between GSI and $K$ for the total samples were analysed with Spearman's correlation coefficient. The presence and age of postovulatory follicles (POFs) were identified according to Hunter \& Goldberg (1980) and Hunter \& Macewicz (1985). The POFs were classified into three age classes: day $0=$ new POF, indicating that the females spawned approximately 24 hours prior; day $1=$ spawning occurred between 24 and $48 \mathrm{~h}$ ago; and day $2=$ old POF in which spawning occurred more than 48 hours before being caught.

The prevalence of atresia (PA) was defined as the number of fish containing ovaries with at least one phase of atretic oocytes relative to the number of all individuals examined, expressed as a percentage (Ganias et al. 2008). The presence/absence of atresia was modelled using a generalized linear model (GLM) with a binomial error distribution for the response variable and a logit link function (Ganias et al. 2008). Prior to selection of variables to be included in the GLM for presence/absence of atresia, Spearman's correlations were performed to detect collinearity between the quantitative variables (FL, $K$, GSI and SST). The explored explanatory variables were FL, $K$, GSI, POF, SST and month/year (MY). Three models were performed. The first model included as response variable all atresia phases identified (alpha, beta and gamma) and their combinations, the second model included only A-atresia, and the third model included only B-atresia. The selection of the best models was checked with Akaike's Information Criterion (AIC) and Deviance $\left(\mathrm{D}^{2}\right)$. Additionally, the Receiver Operating Characteristic (ROC) curve was used to evaluate the sensitivity and specificity of the models.

For females with alpha-atresia, the intensity of atresia (IA) was calculated as the number of alpha-atretic oocytes divided by the total number of vitellogenic oocytes (alphaatresia + non-atretic follicles) following Nunes et al. (2011). Simple counting from histological sections was used as a proxy of intensity of atresia (Ganias et al. 2008, Nunes et al. 2011). The IA was evaluated using a generalized linear model (GLM) with a normal distribution for the response variable and a log link function. The explanatory variables included in the model were FL, $K$, SST and MY.

Batch fecundity (BF) was estimated via gravimetric methods on hydrated females (Hunter \& Macewicz 1985b) in order to compare contribution of hydrated eggs in spawning seasons showing atresia or POF. Three female stages were identified: females non-atretic oocytes ( $\mathrm{n}=$ $71)$, females with atretic oocytes $(n=41)$ and females with presence of POF $(n=66)$. Batch fecundity (FB), defined as the number of oocytes released per spawning event, was determined as the number of hydrated oocytes in actively spawning ovaries. Two pieces of ovary were removed from the middle parts of the gonad and weighed (approx. $0.2 \mathrm{~g}$ ), and hydrated oocytes were counted. These hydrated females were caught during the spawning period S6 (November and December to 2014). Relative batch fecundity (RF), defined as the number of hydrated oocytes per gram of body weight, was determined by dividing BF by BW. Significance differences in BF and RF amongst three female stages were evaluated using Kruskal-Wallis tests and the Dunn a posteriori test. In this case, effects of the explicatory variables FL, $K$ and female stages for BF and RF were tested with a generalized linear model (GLM) with a Poisson distribution for the response variable and a log link function. GLM analysis and ROC curve were performed in R Software (R Core Team 2016). 


\section{ReSUltS}

\section{REPRODUCTION AND CONDITION}

Fork length (FL) for the whole sample ranged from 23 $\mathrm{cm}$ to $64 \mathrm{~cm}$ (mean $34.1 \mathrm{~cm} \pm 5.2$ ), while the body weight (BW) ranged from $115 \mathrm{~g}$ to $3,090 \mathrm{~g}$ (mean $481 \pm 234$ ). Significant differences were found for FL $(H=946.63, P<$ $0.001)$ and BW $(H=1156.76, P<0.001)$ between month/ year, with the females caught in January 2013 being the smallest ones (Table 1). Also, immature females $(n=43)$ showed differences from matures females $(\mathrm{n}=3607)$ for $\mathrm{FL}$ $(U=15288.5, P<0.0001)$ and BW $(U=18830, P<0.0001)$.

Immature females and developing females were observed at low frequency during several seasons spawning (Fig. 1). Conversely, potentially spawning capable females (range: $2-81 \%$ ) and actively spawning females (range: $8-18 \%$ ) were recorded in all samples except January
2013 , increasing the proportion of regressing (61\%) and regenerating (17\%) females (Fig. 1). The absence of females in the actively spawning reproductive phase and the high frequency of advanced maturity phases (regressing and regenerating) indicated that the long spawning period ended by January.

The Gonadosomatic index (GSI) showed significant differences between the reproductive maturity phases $(H=$ 1414.91, $P<0.05)$; high values (GSI $>5$ ) were observed in females showing the actively spawning phase. Immature females $(n=43)$ showed the lowest GSI values $(G S I<1.0)$ when compared with regressing and regenerating females (Fig. 2). Condition factor $(K)$ ranged from 0.43 to 1.92 (mean $1.12 \pm 0.13$ ), but three females showed $K>2.0$ (data not included) in all spawning periods analysed (Fig. 2), Additionally, $K$ varied between the reproductive phases $(H=47.97, P<0.05)$, although $K$ for immature females did

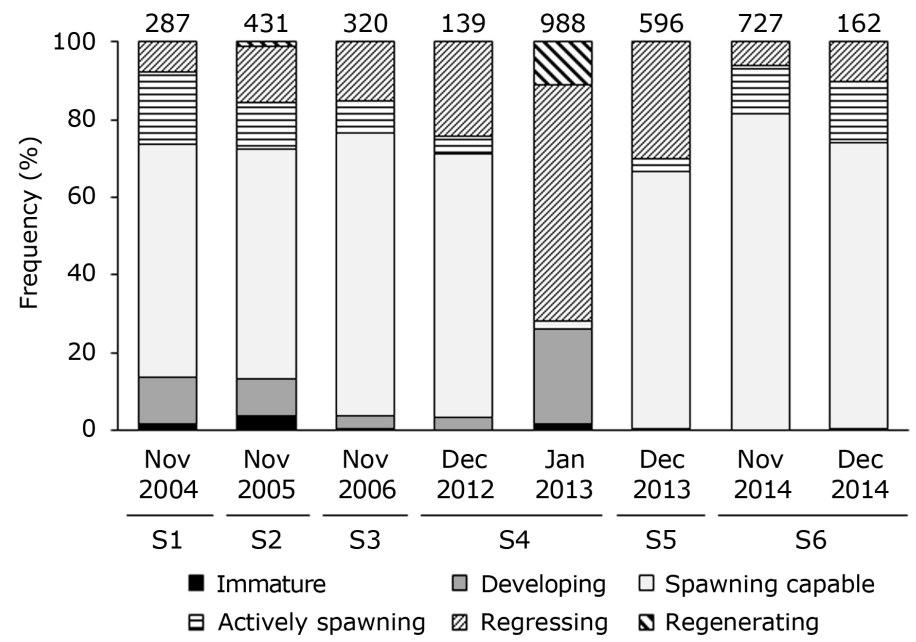

Figure 1. Frequency distribution (\%) of reproductive phase of female Trachurus murphyi for months and spawning seasons (S). Numbers of specimens examined per month are indicated in parenthesis / Distribución de frecuencia (\%) de las fases reproductivas en hembras de Trachurus murphyi por meses y estaciones de desove (S). Número de especímenes examinados por mes son indicados entre paréntesis

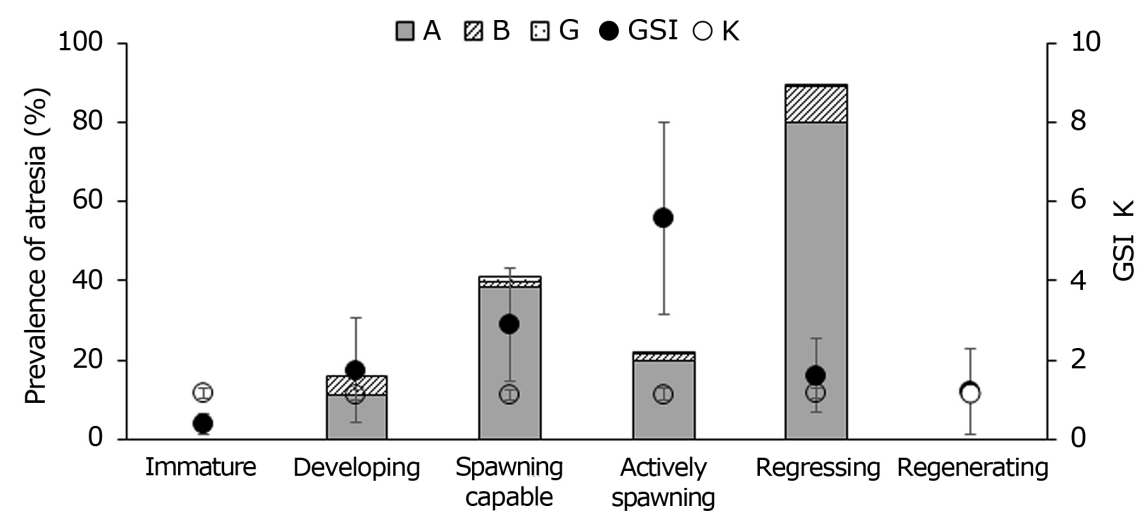

Figure 2. Gonadosomatic Index (GSI), condition factor (K) and prevalence of atresia (\%) for reproductive phase. A= Alpha-atresia, B= Beta-atresia, G= Gamma-atresia / Índice Gonadosomático (GSI) factor de condición (K) y prevalencia de atresia por fase reproductiva. A= Alpha-atresia, B= Betaatresia, $\mathrm{G}=$ Gamma-atresia 
not show differences from mature females $(U=72,788.5, P$ $=0.48)$. Considering the whole sample, GSI was negative (but marginally) correlated with $K(\rho=-0.053, P<0.001)$.

\section{ATRESIA MORPHOLOGY}

Three main sequential stages of atresia were observed: Alpha (A), Beta (B) and Gamma (G) (Fig. 3). For A-atresia three morphological stages were identified: initial (A1), intermediate (A2) and advanced (A3) (Fig. 3b, c, d). During A-atresia, follicular diameter diminished gradually. The first signal for A1-atresia was an internal, non-smooth zona radiata, which subsequently showed a small fragmentation (Fig. 3b). Some oocytes may show thickening of zona radiata before their fragmentation. Additionally, the disintegration of the nucleus is evident from dark basophilic staining. At this stage, the oocyte retains its shape and sometimes looks like a healthy oocyte.
In A2-atresia, the disintegration and fragmentation of the zona radiata were evident and broke up into irregularly shaped segments; also, unstained vacuoles were apparent inside the ooplasm (Fig. 3c). For the A3-atresia phase, the follicle had the appearance of beta-atresia, but few yolk globule follicles were evident when compared with the other stages (Fig. 3d). A decreased prevalence was evident for the three A-atresia sub-stages from the initial stage to the advanced one, $67 \%$ in A1-atresia (initial), $52 \%$ in A2atresia (intermediate) and $24 \%$ in A3-atresia (advanced). These sub-stages of A-atresia can also co-occur, where the combination of sub-stages A1-atresia and A2-atresia was the most prevalent $(\mathrm{PA}=38 \%)$. B-atresia was characterized by the presence of many empty vacuoles and some blood vessels (Fig. 3e). The G-atresia was characterized by yellow-brown granular pigments inside the granulose cells (Fig. 3f).
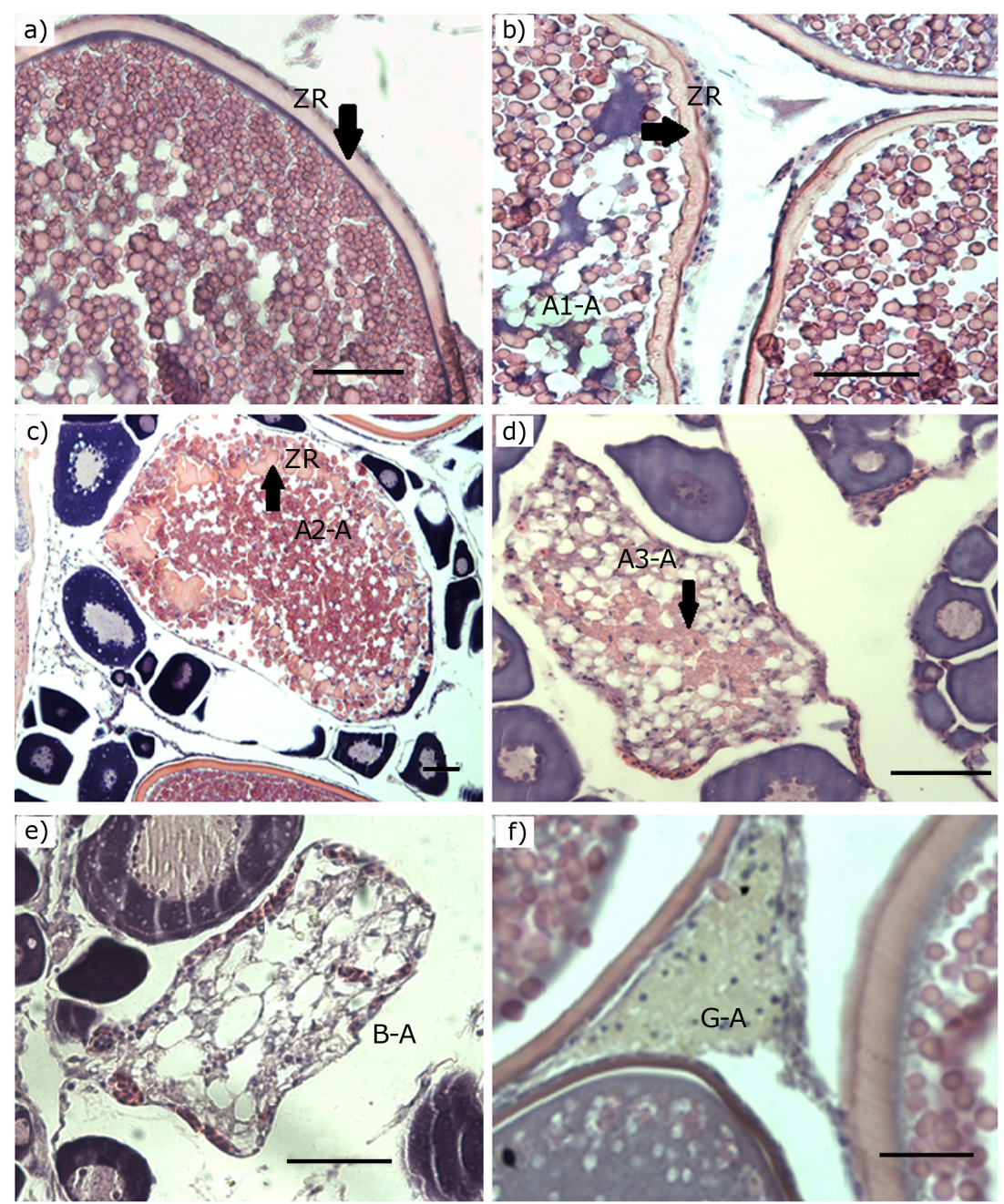

Figure 3. Atretic follicles in Trachurus murphyi. Histological sections were stained with haematoxylin and eosin. a) non atretic oocyte, b) A1-A= initial alpha atresia, c) A2-A= intermediate atresia oocytes, d) A3-A= advance alpha stage atresia, e) B-A= beta atresia oocyte, and f) G-A= gamma atresia. ZR= Zona radiata, black arrows. Scale bar $\mathbf{5 0} \boldsymbol{\mu m}$ / Folículos atrésicos en Trachurus murphyi. Secciones histológicas fueron teñidas con hematoxilina y eosina. a) ovocito no atrésico, b) $A 1-A=$ atresia alpha inicial, c) $A 2-A=$ atresia alpha intermedia, d) $A 3-A=$ atresia alpha avanzada, e) $B-A=$ beta atresia, and f) $G-A=$ gamma atresia. $Z R=$ Zona radiata, flecha negra. Barra $=50 \mu \mathrm{m}$ 


\section{Prevalence of atresia}

Overall and during all months/year were identified atretic oocytes, being Alpha (A)-atresia the most frequently stage observed (Fig. 4). For A-atresia $(n=1,485)$, the $39 \%$ co-occur with a combinations of Beta (B)-atresia, Gamma $(\mathrm{G})$-atresia, while with B-atresia $(\mathrm{n}=107)$ the $74 \%$ of ovaries co-occurs with G-atresia (Fig. 4). Females in regenerating reproductive phases not showed atresia. Alpha-atresia was the most prevalent stage in the remaining reproductive phases, including females with hydrated oocytes that showed A-atresia and B-atresia (Fig. 2 ). Females in the regressing reproductive phase showed prevalence of atresia $>80 \%$ due to higher co-occurrence of A-atresia and B-atresia (Fig. 2). Also, 27\% of mature females recorded post ovulatory follicles (POFs) in all reproductive phases, except the regenerating phase. Thirtytwo per cent of females exhibited POFs in co-occurrence with atresia, mainly A-atresia. The prevalence of POFs at age 0 was higher in females with hydrated oocytes. The frequency of B-atresia and G-atresia increased with POFs at age 1 and age 2 .

The GLM showed that MY, SST and incidence of POF were the variables showing higher effect on PA in the three evaluated models. As FL was significantly correlated with GSI (Spearman's correlations $\rho, P<0.001$ ) was excluded from the analysis. GSI were not significative for explain the presence of atresia in model 2 (Alpha-atresia) while $K$ in all evaluated models (Table 2 ). In the three models, the proportion of explained variance (deviance) was low but significant. Additionally, the prediction of the models was $\operatorname{good}(\mathrm{ROC}=0.8)($ Table 2$)$.
Table 2. Chi-Square values of the binomial GLM model analysing the effects of sea surface temperature (SST), gonadosomatic index (GSI), condition factor $(\mathrm{K})$, presence/absence of postovulatory follicles (POF) and month/year (MY) on the prevalence (presence-absence) of atresia and normal GLM for intensity of atresia in Chilean jack mackerel Trachurus murphyi. Model 1= all atresia stages and their combinations, model $2=$ only alpha atresia and model $3=$ only beta atresia. AIC= Akaike's Information Criterion, $D^{2}=$ deviance of model, $A U C=$ area under ROC curve, $n=$ number total females / Valores de Chi-cuadrado del modelo GLM binomial analizando el efecto de la temperatura superficial del mar (SST), índice gonadosomático (GSI), factor de condición (K), presencia/ausencia de folículos postovulatorios (POF) y meses/año (MY) sobre prevalencia (presencia-ausencia) de atresia y normal GLM para intensidad de atresia en el jurel Trachurus murphyi. Modelo $1=$ todos los estados de atresia y sus combinaciones, modelo 2 = solo Alpha atresia y modelo $3=$ sólo beta atresia. $\mathrm{AIC}=$ Criterio de información de Akaike, $\mathrm{D}=$ Deviance del modelo, $\mathrm{AUC}=$ área bajo curva ROC, $\mathrm{n}=$ número total de hembras

\begin{tabular}{lcccc}
\hline \multicolumn{3}{c}{ Prevalence atresia } & \multirow{2}{*}{$\begin{array}{c}\text { Intensity } \\
\text { atresia }\end{array}$} \\
\cline { 2 - 4 } & Model 1 & Model 2 & Model 3 & \\
\hline SST & $194.67^{* *}$ & $43.77^{* *}$ & $63.03^{* *}$ & $34.25^{* *}$ \\
GSI & $63.29^{* *}$ & $0.02^{\text {n.s }}$ & $25.87^{* *}$ & $0.27^{\text {n.s }}$ \\
K & $0.31^{\text {n.s }}$ & $2.58^{\text {n.s }}$ & $0.37^{\text {n.s }}$ & $6.79^{* *}$ \\
POF & $3.50^{*}$ & $4.96^{*}$ & $8.54^{*}$ & $10.50^{* *}$ \\
MY & $470.21^{* *}$ & $391.94^{* *}$ & $81.07^{* *}$ & $422.17^{* *}$ \\
Criteria & & & & \\
AIC & 3509.1 & 2506.4 & 423.06 & 254285 \\
D & 17.35 & 15.15 & 30.95 & \\
AUC & 0.75 & 0.73 & 0.88 & \\
n & 3606 & 2881 & 2076 & 2881 \\
\hline
\end{tabular}

${ }^{\text {n.s }}$ non-significant; $* 0.05>P>0.01 ; * * P<0.001$

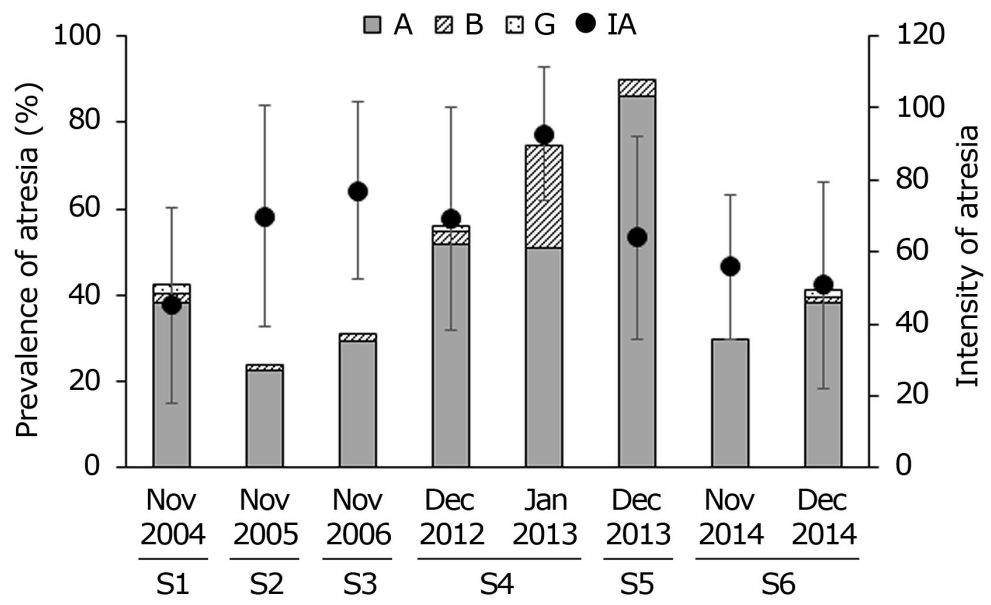

Figure 4. Prevalence of atresia (\%) and intensity of atresia (IA) for months and spawning seasons (S). A= Alpha-atresia, B= Betaatresia, G= Gamma-atresia / Prevalencia de atresia (\%) e intensidad de atresia (IA) por mes y estación de desove (S). A= Alpha-atresia, $\mathrm{B}=$ Beta-atresia, $\mathrm{G}=$ Gamma-atresia 


\section{INTENSITY OF ATRESIA}

Intensity of atresia (IA) was high in all spawning periods (range: 45-77\%); January 2013 showed the highest value of IA $(92 \%)$, confirming that this month corresponded to the end of the spawning period (Fig. 4). GLM showed that MY, SST, POF and $K$ were variables that explained the IA, with MY being the most important variable (Table 2).

\section{FECUNDITY}

Batch fecundity (BF) estimated for females that no showed atresia or postovulatory follicle (POF) ranged from 6200.0 to 114566.8 hydrated oocytes (mean $35293.55 \pm 23955.4$ ), while relative fecundity (RF) ranged from 14.2 to 185.2 (mean $69.7 \pm 32.8$ ) (Fig. 5). Fork length was significantly correlated with BF and RF (Spearman's correlations $\rho$; $P<0.001$ for both). $K$ was only correlated with $\mathrm{BF}$ ( $\rho=$ $0.014, P=0.047)$ but not with RF $(\rho=0.06, P=0.37)$. Both fecundities varied between stages of females: non-atretic females and females with atretic oocytes and females with POF (Fig. 5). Females showing POF showed the lowest BF (mean 28,588.3 $\pm 18,542.2$ ) and RF (mean 54.62 \pm 25.98 ). Females with POF showed significance difference with non-atresia females for batch fecundity (BF) $(H=9.61, P$ $=0.008$, Dunn, $P<0.05)$ and relative fecundity $(\mathrm{RF})(H=$ $7.48, P=0.02$, Dunn, $P<0.05)$. GLM showed that $\mathrm{BF}$ and RF were significantly explained for FL, $K$ and stage of females (non-atretic, atretic and POF), being FL the most important explanatory factor (Table 3 ).

Table 3. Chi- Square values of the Poisson GLM model analysing the effects of fork length ( $F L)$, condition factor $(K)$, and female stage [non-atresia, atresia and postovulatory follicles (POF)] on the batch fecundity and relative fecundity for Chilean jack mackerel Trachurus murphyi / Valores de Chi-cuadrado del modelo GLM Poisson analizando los efectos de la longitud horquilla (FL), factor de condición (K) y estado de las hembras [no-atresia, atresia y con folículos postovulatorios (POF)] en la fecundidad parcial y fecundidad relativa del jurel Trachurus murphyi

\begin{tabular}{crr}
\hline \multirow{2}{*}{$\begin{array}{c}\text { Explanatory } \\
\text { variable }\end{array}$} & \multicolumn{2}{c}{ Fecundity } \\
\cline { 2 - 3 } & \multicolumn{1}{c}{ Batch } & \multicolumn{1}{c}{ Relative } \\
\hline FL & $110166^{* *}$ & $286.99^{* *}$ \\
$K$ & $116188^{* *}$ & $22.91 * *$ \\
Stage of females & $35479 * *$ & $47.3 * *$ \\
\hline$* * P<0.001$ & &
\end{tabular}
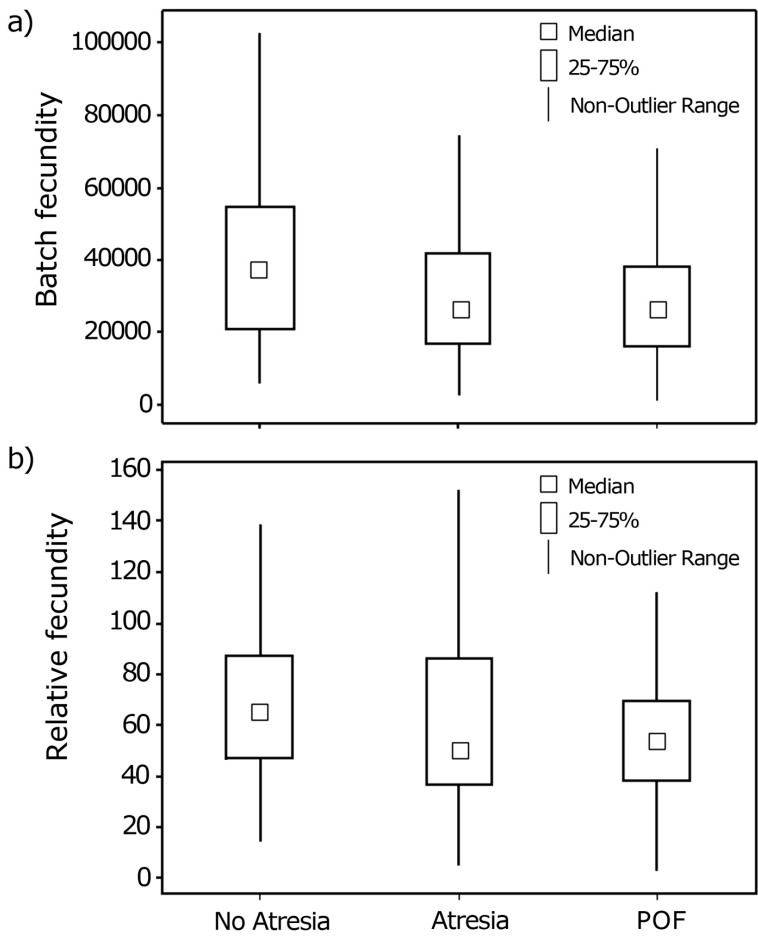

Figure 5. Relationships of batch fecundity(a) and relative fecundity (b) in relation to females stages of Trachurus murphyi [non-atresia, atresia and postovulatory follicle (POF)] / Relación de fecundidad parcial (a) y fecundidad relativa (b) en relación con los estados en hembras de Trachurus murphyi [no-atresia, atresia y folículos postovulatorios (POF)]

\section{Discussion}

Trachurus murphyi showed three mains sequential atretic stages (Alpha, Beta and Gamma), like others Trachurus species (Macewicz \& Hunter 1993, Karlou-Riga \& Economidis 1997, Gordo et al. 2008); being prevalence and intensity of atresia influenced by months/years of spawning seasons. T. murphyi has an extensive spawning season (5 months), can spawn an estimate of 5-14 batches for each reproductive period (Ruiz et al. 2008, Perea et al. 2013), and this condition can explain the co-occurrence of atresia in the different months of the spawning season analysed. Prevalence of Beta-atresia increased strongly at the end of spawning season (January); therefore, the increased proportion of this atresia could be a potential proxy to determine the length of spawning seasons, and it would allow us to detect any change in the current or future reproductive period. During December 2013, the prevalence of atresia $(>80 \%)$ was higher than observed for the same month in other years, suggesting that spawning season began early this year or was shorter. The turnover 
rate for the atretic oocytes in Chilean jack mackerel is unknown, but atretic follicles in fishes are thought to be short lived (Hunter \& Macewicz 1985a, Kjesbu et al. 1991, Kurita et al. 2003). Turnover rates at environmental temperatures for alpha-atretic oocytes have been estimated as 7-9 days for Engraulis mordax Girard, 1854 at $15-16^{\circ} \mathrm{C}$ but with differences between stages of atresia (Hunter \& Macewicz 1985b); 4 to 7 days in Atlantic herring Clupea harengus Linnæus, 1758 for temperatures from 4.2 to 11 ${ }^{\circ} \mathrm{C}$ depending on the month of catch (Kurita et al. 2003); 10 days in cod Gadus morhua Linnæus, 1758 at $8^{\circ} \mathrm{C}$ with a spawning period of 50 days (Kjesbu et al. 1991); and 9 days in sole Solea solea (Linnæus, 1758) (Witthames \& Walker 1995). Understanding trends and dynamics of atretic oocytes in T. murphyi allows us to identify any change in the spawning period, such as a potential skipped spawning (Rideout \& Tomkiewicz 2011) or previous spawning events as has been assessed for Mediterranean sardine Sardina pilchardus (Ganias et al. 2008).

T. murphyi have a reproductive strategy to disperse over their spawning oceanic area associated to SST warmer than 15-16 ${ }^{\circ} \mathrm{C}$ (Cubillos et al. 2008). According to Vasquez et al. (2013), the reproductive activity of T. murphyi is highly correlated with the Subtropical Convergence or Subtropical Front (STF), which separates relatively warm and salty tropical waters from colder and fresher Subantarctic waters (Vasquez et al. 2013, Parada et al. 2017). The results indicate that SST is an important variable explaining the presence of atresia in T. murphyi, and eventually SST higher or lower than the optimal temperature for spawning, could generate a mismatch between reproduction and optimal environmental conditions for progeny development (Miranda et al. 2013). As indicated by Hunter \& Macewicz (1985a) and Witthames \& Walker (1995), spawning events and atresia are temperature-dependent processes, and females can spawn or delay during migration if the temperature regime is not suitable (Ma et al. 1998, Haslob et al. 2013). For yellowtail kingfish Seriola lalandi Valenciennes, 1833 and Sardina pilchardus (Walbaum, 1793), a temperature exceeding the optimal range can cause an aborted spawning event or high prevalence of atresia, respectively (Poortenaar et al. 2001, Ganias 2009, Stuart \& Drawbridge 2013).

In T. murphyi, condition factor $(K)$ significantly affect the intensity but not the prevalence of atresia, suggesting that $K$ is a good index for explain the intensity of atresia because a fish in bad condition will have not enough energy to develop the oocytes and consequently will have a higher intensity of atresia (Hunter \& Macewicz 1985a). Cubillos \& Alarcón (2010) suggested that T. murphyi accumulates energy reserves (autumn-winter) prior to the reproductive process (spring-summer), indicating that this species is capital breeding. As $K$ not showed differences between immature and mature female and the lowest correlation between $K$ with GSI could be an evidence that T. murphyi is an income breeding (i.e., continues to feed during migration) (Bucholtz et al. 2013). To confirm the dynamics of somatic energy, the trends of $K$ should be evaluated during all reproductive cycle of $T$. murphyi. Besides, the relation of GSI and $K$ should be complemented with the evolution of hepatosomatic index (HSI), which is a very good indicator of total energy reserves and fish condition (Zimmermann 1997, Nuñes et al. 2011).

In this study, high values of prevalence of atresia especially the beta-atresia, must be associated with the end of spawning season, which is consistent with an indeterminate type of fecundity (Gordo et al. 2008). In species with indeterminate fecundity such as T. murphyi, the recruitment of oocytes can continue for a long period into the spawning period if adequate food is available (Murua \& Saborido-Rey 2003). Atresia might be considered an important mechanism for the adjustment of fecundity through the resorption of oocytes in unfavourable seasons (Abaunza et al. 2003). The batch fecundity (BF) is an important biological variable for indeterminate spawners and is used in the daily egg production method (DEPM) (Hunter \& Lo 1997, Zwolinski et al. 2001). In this first assessment, the FL, K, presence or absence of atresia and POF affected BF. Fecundity of non-atretic females differed significantly from POF females, coinciding with Macewicz \& Hunter (1993), who indicated that for $T$. symmetricus, the batch fecundity was lower for recently spawned females than females without evidence of a previous spawning event (POF).

Regarding the relative fecundity (RF), the results showed that $T$. murphyi recorded the lowest values (69 oocytes $\mathrm{g}^{-1}$ in non-atretic females) when compared with other Trachurus spp., 172-250 oocytes $\mathrm{g}^{-1}$ in T. trachurus (Karlou-Riga \& Economidis 1997, Abaunza et al. 2003), 112 oocytes $\mathrm{g}^{-1}$ T. symmetricus (Macewicz \& Hunter 1993). The fecundity is known to vary due to nutritional conditions of the spawner (Kurita et al. 2003), but during the spawning season analysed (November-December 2014) $K$ did not show a significant relationship with RF, suggesting that $K$ is not a good proxy for RF. This result agrees with those for Trachurus trachurus, where $K$ and lipid content are not reliable indices as proxy for fecundity (Van Damme et al. 2014). In T. murphyi, are needed further studies on seasonal dynamics of atresia through the whole maturation cycle, and thus be able to understand the trend of atresia with the body condition (i.e., GSI, K and HSI), environmental variables (i.e., temperature) and fecundity of this specie during the whole spawning season. 


\section{ACKNOWLEDGMents}

Data obtained from projects FIP 2004-33, FIP 2005-11, FIP 2006-05, FIP 2012-10, FIP2013-31 and CBJA2014 were provided by Instituto de Investigación Pesquera (INPESCA, Chile; www.inpesca.cl). P. González-Kother thanks CONICYT N² 21130197 doctoral scholarship and CONICYT+PAI/ ATRACCION DE CAPITAL HUMANO AVANZADO DEL EXTRANJERO + Folio NPAI80160001. M.E. Oliva was supported by MINEDUC-UA Project, code ANT 1855.

\section{LITERATURE CITED}

Abaunza P, L Gordo, C Karlou-Riga, A Murta, ATGW Eltink, MT García, C Zimmermann, C Hammer, P Lucio, SA Iversen, J Molloy \& E Gallo. 2003. Growth and reproduction of horse mackerel, Trachurus trachurus (Carangidae). Reviews in Fish Biology and Fisheries 13: 27-61.

Arcos DA, L Cubillos \& SP Núñez. 2001. The jack mackerel fishery and El Niño 1997 - 98 effects off Chile. Progress in Oceanography 49: 597-617.

Ashford J, R Serra, JC Saavedra \& J Letelier. 2011. Otolith chemistry indicates large-scale connectivity in Chilean jack mackerel (Trachurus murphyi), a highly mobile species in the Southern Pacific Ocean. Fisheries Research 107: 291-299.

Bertrand A, MA Barbieri, J Córdova, C Hernández, F Gómez \& F Leiva. 2004. Diel vertical behaviour, predatorprey relationships and occupation of space by jack mackerel (Trachurus murphyi) off Chile. ICES Journal of Marine Science 61: 1105-1112.

Brown-Peterson NJ, DM Wyanski, DM Saborido-Rey, BJ Macewicz \& SK Lowerre-Barbieri. 2011. A standardized terminology for describing reproductive development in fishes. Marine and Coastal Fisheries: Dynamics, Management, and Ecosystem Science 3: 52-70.

Bucholtz RH, J Tomkiewicz, JR Nyengaard \& J Andersen. 2013. Oogenesis, fecundity and condition of Baltic herring (Clupea harengus L.): A stereological study. Fisheries Research 145: 100-113.

Cárdenas L, AX Silva, A Magoulas, J Cabezas, E Poulin \& FP Ojeda. 2009. Genetic population structure in the Chilean jack mackerel, Trachurus murphyi (Nichols) across the South-eastern Pacific Ocean. Fisheries Research 100: 109-115.

Cubillos L \& C Alarcón. 2010. Estimación de la talla media de madurez sexual en Trachurus murphyi mediante parámetros del consumo relativo de oxígeno. Latin American Journal of Aquatic Research 38: 178-187.

Cubillos LA, J Paramo, P Ruiz, S Núñez \& A Sepúlveda. 2008. The spatial structure of the oceanic spawning of jack mackerel (Trachurus murphyi) off central Chile (19982001). Fisheries Research 90: 261-270.

Dragon AC, I Senina, NT Hintzen \& P Lehodey. 2018. Modelling South Pacific jack mackerel spatial population dynamics and fisheries. Fisheries Oceanography 27: 97113.
Ganias K. 2009. Linking sardine spawning dynamics to environmental variability. Estuarine Coastal and Shelf Science 84: 402-408.

Ganias K, C Nunes \& Y Stratoudakis. 2008. Use of late ovarian atresia in describing spawning history of sardine Sardina pilchardus. Journal of Sea Research 60: 297-302.

George MR. 1995. Aspects of the reproductive cycle of southern Pacific jack mackerel, Trachurus murphyi Nichols, 1920, off northern coast of Chile. ICES CM 1995/H30 30: $1-12$.

Gerlotto F, M Gutiérrez \& A Bertrand. 2012. Insight on population structure of the Chilean jack mackerel (Trachurus murphyi). Aquatic Living Resources 25: 341355.

Gordo LS, A Costa, P Abaunza, P Lucio, ATGW Eltink \& I Figueiredo. 2008. Determinate versus indeterminate fecundity in horse mackerel. Fisheries Research 89: 181185.

Haslob H, S Rabade-Uberos \& F Saborido-Rey. 2013. Seasonal variability of fecundity and spawning dynamics of Baltic sprat. Fisheries Research 138: 99-109.

Hunter JR \& SR Goldberg. 1980. Spawning incidence and batch fecundity in northern anchovy, Engraulis mordax. Fishery Bulletin 77(3): 641-652.

Hunter JR \& NH Lo. 1997. The daily egg production method of biomass estimation: some problems and potential improvements. Ozeanografika 2: 41-69.

Hunter JR \& BJ Macewicz. 1985a. Rates of atresia in the ovary of captive and wild northern anchovy; Engraulis mordax. Fishery Bulletin 83: 129-136.

Hunter JR \& BJ Macewicz. 1985b. Sexual maturity, batch fecundity, spawning frequency, and temporal pattern of spawning for the northern anchovy, Engraulis mordax, during the 1979 spawning season. CalCOFI Report 31: 139-149.

Karlou-Riga C \& PS Economidis. 1997. Spawning frequency and batch fecundity of horse mackerel, Trachurus trachurus (L.), in the Saronikos Gulf (Greece). Journal of Applied Ichthyology 13: 97-104.

Kjesbu OS, J Klungsoyr, H Kryvii, PR Whitames \& M Greer-Walker. 1991. Fecundity, atresia and egg size of captive cod (Gadus morhua) in relation to proximate body composition. Canadian Journal of Fisheries and Aquatic Sciences 48: 2333-2343.

Kurita Y, S Meier \& OS Kjesbu. 2003. Oocyte growth and fecundity regulation by atresia of Atlantic herring (Clupea harengus) in relation to body condition throughout the maturation cycle. Journal of Sea Research 49: 203-219.

Leal E, E Díaz, JC Saavedra-Nievas \& G Claramunt. 2013. Ciclo reproductivo, longitud y edad de madurez de jurel Trachurus murphyi, en la costa de Chile. Revista de Biología Marina y Oceanografía 48: 601-611.

Lowerre-Barbieri SK, NJ Brown-Peterson, H Murua, J Tomkiewicz, DM Wyanski \& F Saborido-Rey. 2011. Emerging issues and methodological advances in fisheries reproductive biology. Marine and Coastal Fisheries: Dynamics, Management, and Ecosystem Science 3: 32-51. 
Ma Y, OS Kjesbu \& T Jorgensen. 1998. Effects of ration on the maturation and fecundity in captive Atlantic herring (Clupea harengus). Canadian Journal of Fisheries and Aquatic Sciences 55: 900-908.

Macewicz BJ \& J Hunter. 1993. Spawning frequency and batch fecundity of jack mackerel, Trachurus symmetricus, off California during 1991. CalCOFI Report 34: 112-121.

Murua H \& F Saborido-Rey. 2003. Female reproductive strategies of marine fish species of the North Atlantic. Journal of the Northwest Atlantic Fishery Science 33: 23-31.

Nunes C, A Silva, E Soares \& K Ganias. 2011. The use of hepatic and somatic indices and histological information to characterize the reproductive dynamics of Atlantic sardine Sardina pilchardus from the Portuguese coast. Marine and Coastal Fisheries: Dynamics, Management, and Ecosystem Science 3: 127-144.

Parada C, A Gretchina, S Vásquez, A Belmadani, V Combes, B Ernst, E Di Lorenzo, J Porobic \& A Sepulveda. 2017. Expanding the conceptual framework of the spatial population structure and life history of jack mackerel in the eastern South Pacific: an oceanic seamount region as potential spawning/ nursery habitat. ICES Journal of Marine Science 74: 2398-2414.

Perea A, J Mori, B Buitón \& J Sánchez. 2013. Aspectos reproductivos del jurel Trachurus murphyi. En: Csirke J, R Guevara-Carrasco \& M Espino (eds). Ecología, pesquería y conservación del jurel (Trachurus murphyi) en el Perú. Revista Peruana de Biología 20: 29-34.

Poortenaar CW, SH Hooker \& N Sharp. 2001. Assessment of yellowtail kingfish Seriola lalandi lalandi reproductive physiology, as a basis for aquaculture development. Aquaculture 201: 271-286.

Poulin E, L Cárdenas, CE Hernandez, I Kornfield \& FP Ojeda. 2004. Resolution of the taxonomic status of Chilean and Californian jack mackerels using mitochondrial DNA sequence. Journal of Fish Biology 65: 1160-1164.

R Core Team. 2016. R: A language and environment for statistical computing. R Foundation for Statistical Computing, Vienna. $<$ https://www.R-project.org/>

Rideout RM \& J Tomkiewicz. 2011. Skipped spawning in fishes: More common than you might think. Marine and Coastal Fisheries 3: 176-189.

Ruiz P, A Sepúlveda, L Cubillos, C Oyarzún \& J Chong. 2008. Reproductive Parameters and spawning biomass of Chilean Jack mackerel (Trachurus murphyi), in 1999-2008 determined by the daily egg production method. In: Eight International Meeting. SWG, Jack Mackerel Sub-Group SP-08-SWG-JM-02: 1-11. International Consultations on the Establishment of the South Pacific Regional Fisheries Management Organization, Auckland.
Saborido-Rey F \& OS Kjesbu. 2005. Growth and maturation dynamics, 26 pp. <http://hdl.handle.net/10261/47150>

Sepúlveda A, P Ruiz, RA Muñoz, S Nuñez, R Bahamonde, R Córdova, J Chong, H Rebolledo, M Aguayo \& L Bustos. 2009. Condición biológica del jurel en alta mar, año 2006. Informe Final FIP 2006-05: 1-291. <http://www.subpesca. cl/fipa/613/articles-89128_informe_final.pdf $>$

Serra R. 1991. Important life history aspects of the Chilean jack mackerel, Trachurus symmetricus murphyi. Investigación Pesquera 36: 67-83.

SUBPESCA. 2018. Cuota global anual de captura de jurel para las unidades de pesquería de las Regiones de Arica Parinacota y Antofagasta, Atacama y Coquimbo, Valparaíso y la Araucanía, y de los Ríos y de los Lagos, año 2019. Informe Técnico (R. PESQ.) 304-2018: 1-11. Subsecretaría de Pesca y Acuicultura, Valparaíso. $<$ http:// www-old.subpesca.cl/transparencia/documentos/2018/ RPESQ_304-2018_Cuota_jurel_XV_X_Regs_2019. pdf $>$

Stuart KR \& MA Drawbridge. 2013. Captive spawning and larval rearing of California yellowtail (Seriola lalandi). Aquaculture Research 44: 728-737.

Taylor PR. 2002. Stock structure and population biology of the Peruvian jack mackerel, Trachurus symmetricus murphyi. New Zealand Fisheries Assessment Report 2002/21: 1-78.

Van Damme CJG, A Thorsen, M Fonn, P Alvarez, D Garabana, B O'Hea, J Perez \& M Dickey-Collas. 2014. Fecundity regulation in horse mackerel. ICES Journal of Marine Science 71: 546-558.

Vásquez S, M Correa-Ramírez, C Parada \& A Sepúlveda. 2013. The influence of oceanographic processes on jack mackerel (Trachurus murphyi) larval distribution and population structure in the southeastern Pacific Ocean. ICES Journal of Marine Science 70: 1097-1107.

West G. 1990. Methods of assessing ovarian development in fishes: a review. Australian Journal of Marine and Freshwater Research 41: 199-258.

Witthames PR \& MG Walker. 1995. Determinacy of fecundity and oocyte atresia in sole (Solea solea) from the Channel, the North Sea and the Irish Sea. Aquatic Living Resources 8: 91-109.

Zimmermann M. 1997. Maturity and fecundity of arrowtooth floundeer Atheresthes stomias, from the Gulf of Alaska. Fishery Bulletin 95: 598-611.

Zwolinski J, Y Stratoudakis \& E Soares. 2001. Intra-annual variation in the batch fecundity of sardine off Portugal. Journal of Fish Biology 58: 1633-1645. 